\title{
REGULASI INDUSTRI TELEKOMUNIKASI NASIONAL DALAM PERSPEKTIF HUKUM PERSAINGAN USAHA
}

Oleh :

\section{AriPurwadi}

\begin{abstract}
Industrial regulation of telecommunication has been arranged by Act No. 36 Year 1999 that has given chances for pro-competition and anti-monopoly. Government policies on telecommunication have not opened the chances widely due to telecommunication performance exclusively or in such duopoly manner. Practically, conducts that lead to unhealthy competitions in implementation of telecommunication are still found.
\end{abstract}

Key words : telecommunication industry, monopoly, unhealthy competition, exclusive rights, duopoly.

\section{PENDAHULUAN}

Pada waktu ini reformasi telekomunikasi dilaksanakan praktis oleh semua negara di dunia. $\mathrm{Hal}$ ini terutama disebabkan oleh perubahan dratis lingkungan ekonomi global dan kepesatan kemajuan teknologi dan informasi. Manifestasi reformasi tersebut berbeda antara negara yang satu dengan yang lain, karena perbedaan yang spesifik pada keadaan ekonomi, politik, dan sosial masing-masing negara. Corak reformasi telekomunikasi yang beraneka ragam ini juga disebabkan oleh sasaran yang ingin dituju oleh strategi reformasi berbeda.

Pada umumnya telekomunikasi mempunyai dimensi global, meskipun bobot tanggungjawabnya berada di ruang lingkup nasional. Hal ini disebabkan karena sifat telekomunikasi itu sendiri inheren dengan jangkauan jarak jauh sehingga mempunyai implikasi global, sedangkan wujud dan bentuk akhirnya sebagian besar ditentukan oleh lingkungan dan kebijakan nasional.

Perubahan lingkungan ekonomi global dan laju kemajuan teknologi telekomunikasi dan informatika yang berlangsung secara dinamis telah mendorong lahirnya lingkungan telekomunikasi yang jauh berbeda dengan keadaan yang telah berlaku begitu lama sebelumnya. Perubahan yang amat mendasar ini menimbulkan realita baru pada penyelenggaraan telekomunikasi di seluruh dunia. 
Secara garis besar, bentuk perubahan dan realita baru ini, antara lain berupa : beralihnya fungsi telekomunikasi dari utilitas menjadi komoditi perdagangan; bergesernya fungsi pemerintah dari memiliki, membangun, dan menyelenggarakan telekomunikasi ke menentukan kebijakan, mengatur, mengawasi dan mengendalikannya; peningkatan peran swasta sebagai investor prasarana dan penyelenggaraan telekomunikasi; transformasi struktur pasar telekomunikasi dari monopoli ke persaingan.

Namun, realitas yang terjadi terdapat keluhan-keluhan terhadap industri telekomunikasi di Indonesia. Ketika bisnis telekomunikasi makin marak dan ketika masyarakat mulai diuntungkan karena persaingan membawa pada pilihan, namun ketika itu pula kekhawatiran mulai muncul. Industri telekomunikasi yang pelakunya semakin meraksasa ternyata makin menutup kemungkinan pendatang baru untuk ikut mengisi celah pasar yang ada. Dewasa ini ada raksasa-raksasa industri telekomunikasi di bisnis telepon tetap (fixed) dipegang oleh PT. Telkom sebagai incumbent (penyelenggara dominan). (Moch.S. Hendrowiyono; 2004 : 37)

Pemerintah dinilai cuma setengah hati membuka pintu persaingan industri telekomunikasi. Bahkan dapat dikatakan nyaris tidak ada pemain baru. Pada bisnis SLI dan SLJJ, cuma ada 2 pemain, yaitu PT. Telkom dan PT. Indosat yang diperbolehkan. Itupun PT. Indosat belum punya apaapa. Untuk sambungan tetap lokal ada tambahan satu pemain, yaitu Bakrie Telecom, itu pun cuma boleh beroperasi di Jakarta dan Jawa Barat. Persaingan industri telekomunikasi dibiarkan lebih terbuka pada telepon selular. (Abdulrahman; 2004: 38)

Instrumen hukum yang mengatur industri telekomunikasi berupa Undang-Undang Nomor 3 Tahun 1989 Tentang Telekomunikasi, yang kemudian diubah dengan Undang-Undang Nomor 36 Tahun 1999 Tentang Telekomunikasi (untuk selanjutnya ditulis UU Telekomunikasi). UU Telekomunikasi Tahun 1989 masih terlihat kerangka hukum yang bernuansa monopoli dalam penyelenggaraan telekomunikasi di Indonesia. Hal ini dapat dilihat pengaturan yang ada pada UU Telekomunikasi Tahun 1989, antara lain :

- Penyelenggaraan telekomunikasi dilaksanakan oleh pemerintah, yang selanjutnya untuk penyelenggaraan jasa telekomunikasi dapat dilimpahkan kepada badan penyelenggara.

- Badan penyelenggara adalah Badan Usaha Milik Negara (BUMN) yang dibentuk untuk itu sesuai dengan peraturan perundang-undangan yang berlaku.

- Jasa telekomunikasi dikategorikan sebagai jasa telekomunikasi dasar dan bukan dasar. Jasa telekomunikasi dasar meliputi telepon, telex dan telegram. Jasa telekomunikasi bukan dasar adalah jasa telekomunikasi di luar jasa telekomunikasi dasar.

- Badan hukum di luar badan penyelenggara, yang 
juga disebut badan lain, dapat menyelenggarakan jasa telekomunikasi dasar atas kerjasama dengan badan penyelenggara. Untuk menyelenggarakan jasa telekomunikasi bukan dasar badan lain dapat melaksanakannya tanpa kerjasama dengan badan penyelenggara.

- Badan penyelenggara ditentukan ada 2 BUMN, yaitu:

1. PT. Telkom, sebagai satu-satunya badan penyelenggara jasa telekomunikasi dasar untuk jasa telekomunikasi dalam negeri. Jasa telekomunikasi tetap sambungan lokal dan jasa telekomunikasi tetap sambungan langsung jarak jauh nasional. Jasa-jasa tersebut diselenggarakan melalui jaringan telekomunikasi tetap (fixed) atau juga disebut jaringan berdasarkan kawat (wireline). Dengan demikian, PT. Telkom merupakan satu-satunya penyelenggara jaringan umum telekomunikasi tetap dalam negeri;

2. PT. Indosat, sebagai badan penyelenggara jasa telekomunikasi dasar untuk jasa telekomunikasi tetap sambungan internasional hingga tahun 1994. Sejak tahun 1995 ada penyelenggara jasa telekomunikasi tetap sambungan internasional yang kedua, yaitu: PT. Satelindo. Jadi untuk jasa telepon tetap sambungan internasional diselenggarakan secara duopoli, yaitu PT.
Indosat dan PT. Satelindo.

Di sisi lain, perlu diperhatikan adanya faktor ekstern yang mempengaruhi perlunya reformasi kebijakan industri telekomunikasi. Faktor ini adalah adanya suatu kenyataan baru bahwa rezim telekomunikasi nasional telah menjadi bagian dari rezim perdagangan global yang diadministrasikan oleh World Trade Organization (WTO).

Dalam WTO terjadi komitmen liberalisasi pasar jasa telekomunikasi dasar, sehingga terjadi perubahan yang dulu mengenai pelayanan telekomunikasi selalu dianggap sebagai jasa yang nonkomersial dan pada umumnya diselenggarakan oleh negara dalam lingkungan monopoli. Dulu ada konvensi internasional yang dituangkan dalam ITR (International Telecommunications Rule) di bawah payung ITU (International Telecommunication Union) selalu didasarkan pada kedaulatan negara masingmasing dalam mengatur telekomunikasinya. Dengan adanya komitmen negara anggota WTO tersebut, maka terjadi perubahan kelaziman menjadi rezim perdagangan dunia.

Komitmen WTO untuk liberalisasi jasa telekomunikasi dasar didokumentasikan dalam : Jadwal Komitmen Tentang Telekomunikasi Dasar (Schedule Of Commitments on Basic Telecommunications) bagi masing-masing negara anggota. Dalam jadwal komitmen WTO untuk jasa telekomunikasi dasar, maka Indonesia menyatakan antara lain, bahwa : 
- Jasa telekomunikasi tetap sambungan antara lain. bahwa : jarak jauh nasional diselenggarakan secara eksklusif oleh PT. Telkom sampai dengan tahun 2005;

- Jasa telekomunikasi tetap sambungan internasional diselenggarakan secara duopoli oleh PT. Indosat dan PT. Satelindo sampai dengan tahun 2004;

- Jasa telekomunikasi tetap sambungan lokal diselenggarakan secara eksklusif oleh PT. Telkom sampai dengan tahun 2010;

- Jasa telekomunikasi bergerak selular diselenggarakan secara kompetitif oleh penyelenggara yang sahamnya dapat dinilai investor asing sampai 35\%. (Cetak Biru Kebijakan Pemerintah Tentang Telekomunikasi)

Dengan telah dikeluarkan UU Telekomunikasi Tahun 1999, maka Indonesia menangkap adanya perubahan lingkungan global dan perkembangan teknologi telekomunikasi yang berlangsung sangat cepat. UU Telekomunikasi Tahun 1999 telah mengatur perubahan-perubahan tersebut antara lain :

1. Kebijakan pro-persaingan.

2. Pemisahan fungsi pembinaan dan penyelenggaraan.

3. Non-diskriminasi atas dasar struktur kepemilikan.

4. Tarip berorientasikan biaya.

5. Mekanisme perizinan.
6. Interkoneksi.

7. Pelayanan universal.

8. Akses yang setara.

9. Standar teknik.

10. Perlindungan konsumen.

Dalam pasal 10 UU Telekomunikasi Tahun 1999 dengan tegas mengatur :

(1) Dalam penyelenggaraan telekomunikasi dilarang melakukan kegiatan yang dapat mengakibatkan terjadinya praktek monopoli dan persaingan usaha tidak sehat di antara penyelenggara telekomunikasi;

(2) Larangan sebagaimana dimaksud pada ayat (1) sesuai dengan peraturan perundangundangan yang berlaku.

\section{PERMASALAHAN}

Undang-Undang Telekomunikasi Tahun 1999 pada dasarnya hanya menggariskan inti dan pokokpokok kebijakan penyelenggaraan telekomunikasi di Indonesia. Pelaksanaan kebijakan tersebut perlu diikuti oleh perangkat regulasi melalui beberapa jenis instrumen hukum yang sesuai. Oleh karena itu, timbul permasalahan sekitar : apakah regulasi industri telekomunikasi benar-benar bisa mencerminkan kebijakan pro-persaingan?

\section{PEMBAHASAN}

\section{Monopoli Versus Pro-Persaingan}

Dalam kamus Webster's monopoli diartikan "exclusive ownership through legal privilege, com- 
mand of supply, or concerted action". Selanjutnya "Monopoly implies exclusive control of a public service or of exclusive power to buy or sell a commodity in a specified market" (Webster's Third New International Dictionary G \& C Merriam Co; 1963 : 548-549). Demikian juga diartikan monopoli sebagai "the exclusive or virtually exclusive ownership of the source of a commodity or product, or the equivalent control of that commodity or product's distribution". (Rate A. Howell et.al.; 1979 :9-16)

Demikian juga, suatu monopoli didefinisikan sebagai suatu badan usaha yang dengan sengaja melakukan tindakan untuk mendapatkan atau mempertahankan kekuasaan/kekuatan untuk mengendalikan harga atau menyisihkan persaingan dalam beberapa bagian sektor perdagangan. (Dauglas Whitman dan John William Gergacz; 1994, h. 671) Badan usaha yang merupakan satu-satunya yang beroperasi dalam pasar tertentu akan menunjukkan adanya monopoli atau "mempunyai monopoli" dalam pasar. Meskipun ada beberapa badan usaha dalam pasar tertentu, tetapi dalam kenyataannya salah satu diantaranya masih dapat melakukan monopoli kalau badan usaha lainnya tidak mempunyai kekuatan untuk mempengaruhi harga atau output di pasar.

Kebalikan dari monopoli adalah suatu sistem persaingan dengan memasukkan banyak badan usaha yang memproduksi barang atau jasa yang sama, sehingga tidak ada satupun dari badan usaha tersebut mempunyai kekuatan mengendalikan harga atau output. Untuk menentukan apakah ada monopoli atau tidak membutuhkan definisi tentang pasar yang relevan tersebut.

Biasanya suatu pasar didefinisikan baik dalam hal geografisnya maupun dalam hal produknya. Misalnya, anggaplah fakta hipotesis sebagai berikut :

1. Sebuah badan usaha bernama PT. "X", yang berlokasi di Surabaya, memproduksi pembangkit listrik (generator) yang digerakkan dengan mesin diesel untuk ukuran rumah tangga dan menjualnya di seluruh pulau Jawa;

2. Ada beberapa badan usaha/pabrik mesin pembangkit listrik lainnya yang berlokasi di pulau Jawa, namun tak satupun diantaranya yang memproduksi model untul ukuran rumah tangga;

3. Ada badan usaha/pabrik generator untuk ukuran rumah tangga lainnya di Indonesia, namun hanya di Sumatera dan di Papua, dan biaya pengangkutan produk mereka apabila dipasarkan di pulau Jawa sangat mahal sekali.

Berdasarkan fakta hipotesis ini, maka dapat dikatakan bahwa :

PT, "X" mempunyai monopoli di pulau Jawa untuk pembangkit tenaga listrik (generator) dengan mesin diesel untuk ukuran rumah tangga, dan tidak mempunyai monopoli secara umum, serta tidak pula monopoli atas setiap produk pembangkit tenaga listrik di Indonesia. Jadi PT. "X"'ini mempunyai monopoli di pasar produk dan 
geografis tertentu.

Walaupun bisa diargumentasikan bahwa monopoli sebenarnya tidak selalu buruk, karena suatu konsentrasi sumberdaya pada satu badan usaha dapat mengarahkan pada ukuran efisiensi. Akan tetapi pandangan yang lebih luas diterima bahwa monopoli itu buruk (dengan pengecualian tertentu) karena dapat menaikkan harga barang dan atau jasa seenaknya, tanpa adanya disiplin yang dipaksakan oleh adanya persaingan. (John W. Head; h.10)

Dari apa yang diuraikan di atas, maka sebenarnya istilah mengenai pasar, dimana di pasar tersebut tidak tersedia lagi produk substitusi atau produk substitusi yang potensial dan terdapatnya kemampuan badan usaha tersebut untuk menerapkan harga produk tersebut yang lebih tinggi tanpa mengikuti hukum persaingan pasar atau hukum permintaan dan penawaran pasar. Jadi di sini timbul pemusatan kekuatan ekonomi, yaitu adanya penguasaan yang nyata atas suatu pasar bersangkutan oleh segelintir badan usaha, sehingga dapat menentukan harga barang dan / atau jasa.

Menurut Munir Fuady, bahwa dalam ilmu hukum monopoli dikenal beberapa sikap monopolistik yang mesti sangat dicermati dalam rangka memutuskan apakah suatu tindakan dapat dianggap sebagai tindakan monopoli. Selanjutnya, dengan mengutip-pendapat William R. Andersen, mengatakan bahwa sikap monopolistik tersebut adalah sebagai berikut :

1) Mempersulit masuknya para pesaing ke dalam bisnis yang bersangkutan;

2) Melakukan pemasangan (captive) sumber suplai yang penting atau outlet distribusi yang penting;

3) Mendapatkan hak paten yang dapat mengakibatkan pihak pesaingnya sulit untuk menandingi produk atau jasa tersebut;

4) Integrasi ke atas atau ke bawah yang dapat menaikkan persediaan modal bagi pesaingnya atau membatasi akses pesaingnya kepada konsumen atau supplier:

5) Mempromosikan produk secara besarbesaran:

6) Menyewa tenaga-tenaga ahli yang berlebihan;

7) Pembedaan harga yang dapat mengakibatkan sulitnya bersaing dari pelaku pasar lain:

8) Kepada pihak pesaing disembunyikan informasi tentang pengembangan produk, tentang waktu atau skala produksi;

9) Memotong harga secara drastis;

10) Membeli atau mengakuisisi pesaing-pesaing yang tergolong kuat atau tergolong prospektif;

11) Menggugat pesaing-pesaingnya atas tindakan pemalsuan hak paten, pelanggaran hukum anti monopoli dan tuduhan-tuduhan lainnya. (Munir Fuady; 2003 : h. 8-9)

Kalau memang diperlukan adanya pengaturan mengenai monopoli dalam dunia usaha tentu menimbulkan pertanyaan yaitu jika monopoli dilarang, kemudian sejauh mana harus dilarang oleh hukum? Persaingan dalam dunia usaha ditinjau dari aspek positif merupakan hal yang wajar. Persaingan yang saling menguntungkan baik bagi sesama pelaku usaha 
maupun menguntungkan konsumen dan tidak merugikan kepentingan orang lain merupakan unsur pendorong bagi kemajuan usaha. Sebaliknya, di pihak lain, persaingan yang tidak wajar dapat menimbulkan akibat negatif, yang dapat merugikan kepentingan pihak lain. Di dunia usaha pun, persaingan ini tidak dapat dihindarkan karena hakekat praktek usaha (bisnis) itu adalah "bersaing". Persaingan antar pelaku usaha terjadi karena produk salah satu pelaku usaha akan bertemu dengan produk pelaku usaha lain di pasar. (Ari Purwadi; 2000: 77)

Persaingan usaha yang dilakukan dengan tidak wajar tentu akan menimbulkan masalah hukum karena mengganggu kepentingan pihak-pihak yang dirugikan.

Di dalam dunia usaha sangat dijauhkan usaha-usaha untuk melakukan perbuatan-perbuatan dan tindakan-tindakan yang bersifat anti persaingan. Monopoli merupakan salah satu bentuk perbuatan yang bersifat anti persaingan. Monopoli bukanlah suatu perbuatan yang mutlak dilarang, kalau monopoli itu diartikan sebagai dominasi pasar yang diperoleh berdasarkan kemampuan, prediksi, atau kejelian bisnis yang tinggi. Maksudnya adalah dominasi pasar karena permintaan dan kemampuan produsen yang sama besar. Produsen yang kalah bersaing karena permintaan kurang atau tidak ada, sehingga produknya tidak ada di pasar, bukanlah karena adanya monopoli yang diciptakan karena otoritas tertentu. Suatu hal yang biasa, apabila suatu perusahaan tumbuh secara cepat akibat dari penawaran kombinasi antara kualitas dan harga produk yang dikehendaki oleh konsumen, sehingga konsumenlah sebenarnya yang menguasai permintaan pasar atas produk tersebut.

Apabila hal di atas terjadi, maka kegiatan usaha perusahaan tersebut, sebenarnya, telah meningkatkan pertumbuhan ekonomi. Pangsa pasar perusahaan ini tumbuh dengan cepat, sehin gga memiliki kekuatan pasar riil. Perusahaan seperti ini memiliki potensi untuk membina dan memperluas pangsa pasar yang lebih kuat dan besar, sekalipun ada perusahaan lain yang berusaha masuk ke dalam pasar dengan produk yang sejenis. Apabila kekuatan itu makin besar dan luas, maka tidak mustahil pangsa pasar itu dikuasai oleh produk tersebut. Hal ini sebenarnya merupakan monopoli, tetapi yang diciptakan oleh pasar sendiri, karena itu, monopoli ini tidak dilarang.

Monopoli yang sangat dilarang adalah monopoli yang menyebabkan terjadinya pembentukan pasar, pembagian pasar, dan konsentrasi pasar secara sepihak. Suatu perusahaan telah melakukan monopoli apabila pada suatu pasar hanya ada produk yang dihasilkan oleh perusahaan itu dalam suatu wilayah tertentu, dimana perusahaan itu merusakan satusatunya produsen yang memproduksi produk tersebut, dan dengan menutup kemungkinan perusahaan lain untuk memproduksi produk yang sama. Keadaan ini akan berdampak negatif bagi 
masyarakat luas atau konsumen, berupa tidak ada pilihan produk yang tersedia di pasar, sehingga kendali permintaan dan penawaran berada pada satu tangan produsen tersebut. (Ari Purwadi; 2000 : 78)

\section{Pro Persaingan Dalam Konteks Kebijakan Telekomunikasi Nasional}

Persaingan yang sehat di pasar tidak dapat muncul begitu saja tanpa adanya kebijakan persaingan yang baik. Kebijakan persaingan yang baik tentu berupa kebijakan persaingan yang harus meningkatkan persaingan baik ditingkat lokal maupun nasional, serta harus dapat mencegah kebijakan atau perilaku yang menghambat persaingan.

Prinsip-prinsip dasar yang perlu diperhatikan dalam merancang dan menerapkan kebijakan persaingan, yaitu antara lain :

1. Kebijakan persaingan harus bersifat nondiskriminatif terhadap pelaku usaha nasional maupun asing;

2. Kebijakan persaingan ditujukan untuk melindungi persaingan bukan melindungi pelaku usaha dari persaingannya;

3. Kebijakan persaingan harus bersifat komprehensif, yaitumeliputi kebijakan persaingan di pasar barang, jasa maupun faktor produksi:

4. Diperlukan kebijakan dan lembaga yang melindungi proses persaingan serta;

5. Kebijakan persaingan ini dilindungi kerangka hukum dan penegakan hukum. (Haryo
Asaricahyono; $2004: 36$ )

Instrumen hukum yang mengatur kebijakan telekomunikasi adalah Undang-Undang Nomor 36 Tahun 1999 Tentang Telekomunikasi, beserta Peraturan Pemerintah Nomor 52 Tahun 2000 Tentang Penyelenggaraan Telekomunikasi. Kebijakan persaingan dibidang telekomunikasi dengan tegas diatur dalam pasal 10 UU Telekomunikasi Bagian Ketiga : Larangan Praktek Monopoli, yang berbunyi :

(1) Dalam penyelenggaraan telekomunikasi dilarang melakukan kegiatan yang dapat mengakibatkan terjadinya praktek monopoli dan persaingan usaha tidak sehat di antara penyelenggaraan telekomunikasi;

(2) Larangan sebagaimana dimaksud pada ayat (1) sesuai dengan peraturan perundang-undangan yang berlaku.

Pada penjelasan pasal 10 ini dinyatakan bahwa peraturan perundang-undangan yang berlaku dimaksud adalah Undang-Undang Nomor 5 Tahun 1999 Tentang Larangan Praktek Monopoli dan Persaingan Usaha Tidak Sehat, serta peraturan pelaksanaannya.

Undang-Undang Nomor 5 Tahun 1999 memberikan pengertian monopoli adalah suatu penguasaan atas produksi dan atau pemasaran barang dan atau atas penggunaan jasa tertentu oleh satu pelaku usaha atau satu kelompok pelaku usaha (pasal 1 angka 1). Sedangkan yang dimaksud dengan praktek monopoli adalah pemusatan kekuatan ekonomi oleh satu atau lebih pelaku usaha yang mengakibatkan 
dikuasainya produksi dan atau pemasaran atas barang dan atau jasa tertentu, sehingga menimbulkan persaingan usaha tidak sehat dan dapat merugikan kepentingan umum (pasal 1 angka 2). Sedangkan pasal 17 melarang kegiatan monopoli, yaitu yang menyatakan :

(1) Pelaku usaha dilarang melakukan penguasaan atas produksi dan atau pemasaran barang dan atau jasa yang dapat mengakibatkan terjadinya praktek monopoli dan atau persaingan usaha tidak sehat;

(2) Pelaku usaha patut diduga atau dianggap melakukan penguasaan atas produksi dan atau pemasaran barang dan atau jasa sebagaimana dimaksud dalam ayat (1) apabila :

a. Barang dan atau jasa yang bersangkutan belum ada substitusinya; atau

b. Mengakibatkan pelaku usaha lain tidak dapat masuk ke dalam persaingan usaha barang dan atau jasa yang sama; atau

c. Satu pelaku usaha atau satu kelompok usaha menguasai lebih dari 50\% (lima puluh persen) pangsa pasar satu jenis barang atau jasa tertentu.

Jadi agar suatu monopoli dapat dilarang haruslah memasuki unsur-unsur sebagai berikut :

1. Melakukan penguasaan atas produksi suatu produk; dan atau

2. Melakukan penguasaan atas pemasaran suatu produk.

3. Penguasaan tersebut dapat mengakibatkan terjadinya praktek monopoli; dan atau

4. Penguasaan tersebut dapat mengakibatkan terjadinya praktek persaingan usaha tidak sehat, (Munir Fuady; 76)

Apabila ditelusuri mengenai kebijakan telekomunikasi ternyata sejak tahun 1999 sudah terdapat cetak biru (blue print ) kebijakan pemerintah tentang telekomunikasi Indonesia. Dalam cetak biru kebijakan telekomunikasi digambarkan mengenai struktur industri telekomunikasi sebagai berikut :

\begin{tabular}{|c|c|c|c|c|c|}
\hline \multicolumn{5}{|c|}{ Jasa } & Penyelenggaraan \\
\hline \multirow{5}{*}{$\begin{array}{l}\text { Jasa } \\
\text { telekomunikasi } \\
\text { dasar }\end{array}$} & \multirow{4}{*}{ Tetap } & \multirow{3}{*}{ Domestik } & \multirow{2}{*}{$\begin{array}{c}\text { Jasa } \\
\text { telekomunikasi } \\
\text { tetap } \\
\text { sambungan } \\
\text { lokal } \\
\end{array}$} & Kabel & $\begin{array}{c}\text { Eksklusif sejak } 1996 \\
\text { akhir } 2010\end{array}$ \\
\hline & & & & Radio & Persaingan terbatas \\
\hline & & & \multicolumn{2}{|c|}{$\begin{array}{c}\text { Jasa telekomunikasi } \\
\text { tetap sambungan jarak } \\
\text { jauh nasional (SLJJ) }\end{array}$} & $\begin{array}{l}\text { Eksklusif sejak } 1996 \\
\text { hingga akhir } 2005\end{array}$ \\
\hline & & \multicolumn{3}{|c|}{$\begin{array}{c}\text { Jasa telekomunikasi tetap } \\
\text { sambungan internasional (SLI) }\end{array}$} & $\begin{array}{c}\text { Dua penyelenggara sejak } \\
1995 \text { hingga akhir } 2004\end{array}$ \\
\hline & Ber-gerak & \multicolumn{3}{|c|}{$\begin{array}{c}\begin{array}{c}\text { Sistem teekomunikasi bergerak } \\
\text { selular }\end{array} \\
\end{array}$} & $\begin{array}{c}\text { Persaingan (tergantung } \\
\text { pada tersedianya } \\
\text { frekuensi) }\end{array}$ \\
\hline \multicolumn{5}{|c|}{ Jasa telekomunikasi non dasar } & Persaingan \\
\hline \multicolumn{5}{|c|}{ Peralatan terminal palanggan (CPE) } & Persaingan \\
\hline \multicolumn{5}{|c|}{ Peralatan non $\mathrm{CPE}$} & $\begin{array}{l}\text { Dalam proses menuju } \\
\text { persaingan }\end{array}$ \\
\hline
\end{tabular}


Pola penyelenggaraan telekomunikasi di Indonesia ditentukan sekali oleh masih atau sudah tidak adanya eksklusivitas. Ada beberapa jasa telekomunikasi yang tetap masih diizinkan untuk diselenggarakan secara eksklusif atau duopoli sampai waktu tertentu, yaitu :

1. Penyelenggaraan jaringan dan jasa telekomunikasi tetap sambungan internasional diizinkan untuk dilakukan oleh PT. Indosat secara duopoli sampai dengan tahun 2004;

2. Penyelenggaraan jaringan dan jasa telekomunikasi tetap sambungan langsung jarak jauh nasional diizinkan untuk dilakukan oleh PT. Telkom secara eksklusif sampai dengan tahun 2005 ; serta

3. Penyelenggaraan jaringan dan jasa telekomunikasi tetap sambungan lokal diizinkan untuk dilakukan oleh PT. Telkom secara eksklusif sampai dengan tahun 2010.

Oleh karena itu, tindak lanjut dari penyelenggaraan jaringan dan jasa telekomunikasi secara duopoli telah dikeluarkan Surat Keputusan Menteri Perhubungan Nomor 4 Tahun 2004, mulai September 2005 pengelolaan telekomunikasi di Indonesia dikelola dua operator telepon, yaitu PT. Telkom dan PT. Indosat.

Sebenarnya tujuan penghapusan monopoli telekomunikasi melalui pemberian hak duopoli kepada PT Indosat dan PT Telkom dinilai tidak tercapai atau gagal sebagaimana yang diungkap Asmiati Rasyid; pendiri Pusat Studi Regulasi
Telekomunikasi Indonesia.

$\mathrm{Hal}$ ini terbukti dengan tidak adanya percepatan pembangunan infra-struktur telekomunikasi. Bahkan PT Indosat selaku pemain baru dalam layanan lokal cuma tertarik berinvestasi di Jakarta dan Surabaya. Sementara itu di kota lainnya, PT Indosat mencari mitra bisnis dengan sistem pola bagi hasil, artinya dengan memiliki lisensi duopoli PT Indosat tidak usah repot-repot membangun tapi tetap mendapatkan royalty. Hal ini tentu tidak sesuai dengan tujuan pemberian hak duopoli.

PT Indosat selaku penyelenggara layanan sambungan langsung jarak jauh (SLJJ) dan sambungan langsung internasional (SLI) secara langsung menikmati keuntungan bisnis dari hak interkoneksi ke jaringan PT Telkom yang dibangun pemerintah atau PT Indosat mengambil keuntungan dari infrastruktur milik pemerintah yang telah tersedia. PT Indosat sebagai pemegang hak duopoli penyelenggaraan jaringan lokal yang telah diberikan sejak pertengahan tahun 2002, kewajiban membangun infrastruktur tidak dilaksanakan secara efektif. (Kompas; 2004 : 14)

Dengan demikian, tidak ada pembangunan jaringan untuk percepatan pembangunan infrastruktur, sehingga di sini tidak ada persaingan yang sehat dan masih tetap tidak bisa dikatakan adanya produk jasa telekomunikasi berdampak positif bagi konsumen dalam menentukan hak pilihnya. Pada bisnis SLJJ dan SLI cuma ada dua pemain, yaitu PT Telkom dan PT Indosat yang diperbolehkan, itupun PT Indosat belum 
punya apa-apa. Untuk sambungan tetap lokal ada tambahan satu pemain, Bakrie Telecom, itupun cuma boleh beroperasi di Jakarta dan Jawa Barat. Dengan demikian belum terbuka lebar persaingan bisnis SLJJ dan SLI, namun untuk telepon sekular persaingan dibiarkan lebih terbuka. (Abdulrahman, $2004: 38$ )

\section{Persaingan Tidak Sehat : Kasus Pemblokiran}

\section{Akses SLI Indosat}

PT Telkom melakukan pemblokiran atau pembatasan akses telekomunikasi SLI Indosat (Dawrivanto Budhijanto; 2004 : 39), yaitu berupa tindakan PT Telkom agar pengelola Warung Telkom untuk mengabaikan akses SLI Indosat (001 dan 008) dan menggiring konsumennya menggunakan akses SLI Telkom (007 dan 017) melalui perjajian kerjasama. Timbul pertanyaan : apakah perjanjian kerjasama antara PT Telkom dan WT (mitra kerja PT Telkom) ini bisa menciptakan potensi praktek monopoli dan persaingan usaha tidak sehat ?

Apabila perjanjian kerjasama itu merupakan praktek bisnis waralaba (franchising) bukan merupakan pelanggaran hukum persaingan. Undang-Undang Nomor 5 Tahun 1999 di dalam pasal 50 huruf b menetapkan bahwa perjanjian yang berkaitan dengan waralaba dikecualikan dari ketentuan undang-undang ini.

WT merupakan mitra usha Telkom, sehingga wartel berhak untuk hanya memasarkan produk sambungan langsung internasional Telkom dan mengabaikan produk SLI Indosat, kecuali bila keberadaan WT diartikan sebagai warung telekomunikasi, maka pengelola warung telekomunikasi berhak untuk memilih jaringan SLI yang dijual dan PT Telkom tidak dapat menghalangi akses ke operator lain. Penilaian WT diartikan sebagai mitra usaha

PT. Telkom, sejalan dengan pengertian waralaba yang diatur dalam pasal 1 angka 1 Peraturan Pemerintah Nomor 16 Tahun 1997 tentang Waralaba, yaitu: "perikatan dimana satu pihak diberi hak untuk memanfaatkan dan menggunakan hak atas kekayaan intelektual atau penemuan atau ciri khas usaha yang dimiliki pihak lain tersebut, dalam rangka penyediaan dan atau penjualan barang dan atau jasa". WT dikategorikan sebagai mitra usaha PT Telkom karena para pengelola WT ini telah bersepakat menjadi mitra usaha PT Telkom yang dituangkan dalam suatu perjanjian kerjasama. Pertanyaannya adalah apakah perjanjian kerjasama itu bertentangan dengan peraturan perundang-undangan yang berlaku?

Instrumen hukum yang mengatur pertelekomunikasian adalah Undang-Undang Nomor 36 Tahun 1999 Tentang Telekomunikasi dan Peraturan Pemerintah Nomor 52 Tahun 2000 Tentang Penyelenggaraan Telekomunikasi. Pasal 10, 19, dan 25 Undang-Undang Nomor 36 Tahun 1999 pada intinya melarang setiap operator melakukan praktek monopoli dan persaingan usaha tidak sehat, dan mewajibkan mereka menjamin kebebasan 
penggunannya memilih jaringan (mendapatkan interkoneksi) dari operator telekomunikasi lain dalam pemenuhan kebutuhan telekomunikasinya

Penjabaran dari ketentuan ini diterbitkan Keputusan Menteri Perhubungan Nomor 33 Tahun 2004 Tentang Pengawasan Kompetisi Yang Sehat Dalam Penyelenggaraan Jaringan Tetap dan Penyelenggaraan Jasa Teleponi Dasar. A pabila diteliti, maka perjanjian kerjasama tersebut boleh dikatakan melanggar Keputusan Menteri Perhubungan Nomor 33 Tahun 2004, khususnya pasal 4, 6, 7, 8, dan 9 Substansi pasal-pasal tersebu! pada dasarnya melarang operator jaringan maupun jasa telekomunikasi :

1. Menetapkan persyaratan atau memaksa secara langsung atau tidak langsung pengguna atau pelanggannya untuk hanya menggunakan jaringan dan jasa teleponi dasar (SLJJ dan SLI) yang diselenggarakannya.

2. Tidak meneruskan suatu panggilan apabila pengguna atau pelanggan yang terhubung $\mathrm{ke}$ jaringannya memilih penyelenggara lain untuk menyalurkan panggilannya.

3. Melakukan penutupan (blocking) terhadap kode akses tertentu dan mewajibkan setiap penyelenggara jaringan dan jasa teleponi dasar untuk menjamin semua kode akses jasa teleponi dasar SLJJ dan SLI dapat diakses dari setiap terminal pelanggannya secara otomatis.

4. Mengalihkan hubungan ke jaringan lain yang tidak sesuai dengan pilihan pengguna / pelanggan tanpa sepengetahuan pengguna / pelanggan bersangkutan.
5. Tidak memberikan perlakuan yang sama kepada penyelenggara lain dalam pelayanan interkoneksi (Interkoneksi adalah keterhubungan antar jaringan telekomunikasi dari penyelenggara jaringan telekomunikasi yang berbeda (pasal 1 angka 16 UU Telekomunikasi) dan/atau layanan lainnya yang dapat berupa pemenuhan kebutuhan sarana guna pelayanan pelanggan; pembukaan kode akses dan penanganan permintaan interkoneksi, baik dari segi waktu penyediaan, kualitas dimensi maupun biaya.

Pada dasarnya, perjanjian kerjasama PT Telkom dan WT yang disinyalir membatasi akses SLI Indosat juga melanggar ketentuan Undang-Undang Nomor 5 Tahun 1999. Pelanggaran ini tidak hanya terkait dengan ketentuan tentang perjanjian yang dilarang, tetapi juga menyangkut kegiatan yang dilarang. Berkaitan dengan pelanggaran ketentuan tentang perjanjian yang dilarang setidaknya ada 2 (dua) pasal yang dilanggar :

1. Pasal 14 Undang-Undang Nomor 5 Tahun 1999 yang melarang pelaku usaha (operator) membuat perjanjian dengan pelaku usaha lain yang bertujuan menguasai produksi sejumlah produk yang termasuk dalam suatu rangkaian produksi barang dan atau jasa tertentu yang mana setiap rangkaian produksi merupakan hasil pengolahan atau proses lanjutan. Dengan demikian, dominasi Telkom dalam penyelenggaraan jaringan dan jasa lokal, SLJJ, serta upayanya membatasi akses SLI Indosat dapat dianggap sebagai tindakan yang 
bermaksud menguasai sejumlah produk jasa (lokal SLJJ dan SLI).

2. Pasal 15 Undang-Undang Nomor 5 Tahun 1999 melarang pelaku usaha (operator) membuat perjanjian dengan pelaku usaha lain yang memuat persyaratan pihak yang menerima barang dan atau jasa (WT) : 1. Hanya akan memasok atau tidak memasok barang dan atau jasa tersebut kepada pihak tertentu, 2. Harus bersedia membeli barang dan atau jasa dari pelaku usaha pemasok serta tidak akan membeli barang dan atau jasa yang sama dari pelaku usaha lain yang menjadi pesaing pelaku usaha pemasok. Jadi adanya janji kepada setiap mitra usaha Telkom (WT) untuk hanya memasarkan produk SLI Telkom merupakan indikasi adanya pelanggaran substansi pasal 15 tersebut.

Berkaitan dengan pelanggaran terhadap kegiatan yang dilarang oleh Undang-Undang Nomor 5 Tahun 1999 sebagaimana diatur dalam pasal 19. Pasal 19 ini pada intinya melarang pelaku usaha baik sendiri maupun bersama pihak lain untuk:

1. Menolak dan atau menghalangi pelaku usaha tertentu melakukan kegiatan usaha yang sama pada pasar bersangkutan, atau

2. Menghalangi konsumen atau pelanggan usaha pesaingnya atau

3. Membatasi peredaran dan atau penjualan barang dan atau jasa pada pasar bersangkutan.

4. Melakukan praktek diskriminasi terhadap pelaku usaha tertentu.

Dengan demikian, adanya kecenderungan bagi WT untuk hanya menawarkan produk SLI Telkom dapat diindikasikan terjadi pelanggaran terhadap pasal 19 tersebut.

\section{PENUTUP}

Berdasarkan uraian tersebut di atas, maka dapat disimpulkan :

1. Monopoli merupakan suatu keadaan dimana satu badan usaha / pelaku usaha menguasai pasar, sehingga bisa berdampak negatif bagi masyarakat luas atau konsumen berupa tidak ada pilihan produk yang tersedia di pasar;

2. Kebijakan pertelekomunikasian masih menggunakan pola penyelenggaraan telekomunikasi dengan hak ekslusive atau duopoli sampai waktu tertentu. Kebijakan duopoli dinilai gagal karena tidak adanya percepatan pengembangan infrastruktur sehingga belum menumbuhkan pilihan bagi konsumen;

3. Kasus pemblokiran akses SLI Indosat dapat dinilai merupakan pelanggaran baik terhadap Undang-Undang Nomor 5 Tahun 1999 maupun terhadap UU Telekomunikasi beserta peraturan pelaksanaannya, sehingga cenderung menimbulkan perbuatan persaingan tidak sehat dan monopoli. 


\section{DAFTAR PUSTAKA}

Buku

Fuady Munir, Hukum Anti Monopoli (Menyongsong Era Persaingan Sehat), Citra Aditya Bakti, Bandung, 2003.

Head, John W., Pengantar Ilmu Hukum Ekonomi, Edisi Bahasa Indonesia, ELIPS, Jakarta, 1999.

Howell, Rate A. et.al., Business Law, The Drycles Press, Hindale-USA, 1979.

Peraturan Perundang-undangan

Undang-Undang Nomor 5 Tahun 1999 Tentang Larangan Praktek Monopoli dan Persaingan Usaha Tidak Sehat.

Undang-Undang Nomor 36 Tahun 1999 Tentang Telekomunikasi.

Peraturan Pemerintah Nomor 16 Tahun 1997 Tentang Waralaba.

Peraturan Pemerintah Nomor 52 Tahun 2000 Tentang Penyelenggaraan Telekomunikasi.

Keputusan Menteri Perhubungan Nomor 33 Tahun 2004 Tentang Pengawasan Kompetisi Yang Sehat Dalam Penyelenggaraan Jaringan Tetap dan Penyelenggaraan Jasa Teleponi Dasar.

Jurnal/Koran/Dokumen

Purwadi,Ari, "Implikasi Undang-Undang Persaingan Usaha Terhadap Perlindungan Konsumen", Era Hukum, No.1 Th.7 Juli 2000.
Tak Nyaman Untuk Pendatang Baru", Kompas, 15 Juli 2004.

Danrivanto Budhijanto "Perang SLP Berujung ke KPPU", Kompas, 15 Juli 2004.

Haryo Aswicahyono, "Persaingan Pasar", Kompas, 2 September 2004.

"Gagal, Hak Duopoli Telekomunikasi", Kompas, 16 September 2004.

Abdulrahman, "Bebaskan Industri Telekomunikasi, Segera!", Kompas,

6 Oktober 2004.

Cetak Biru (Blue Print) Kebijakan Pemerintah Tentang Telekomunikasi.

Moch.S. Hendrowiyono, "Industri Telekomunikasi 